\title{
Mersin yöresinde Hymenoptera venom duyarllık oranları
}

\section{The sensitization rates of Hymenoptera venom in Mersin region}

\section{Deniz Gezer, Engin Șenel*}

Çankırı Devlet Hastanesi, İç Hastalıklar ve *Deri ve Zührevi Hastalıklar Klinikleri, Çankırı, Türkiye

Özet

Amaç: Arı venomlarına karșı gelișen alerjik reaksiyonlar ciddi sonuçlarının olması nedeniyle önemli bir sağlık sorunu olușturmaktadır. Bu çalıșmayı, arı alerjisinin dolaylı bir ölçüsü olan duyarlılașma oranlarının, Mersin yöresindeki durumunu belirlemek amacıyla yaptık. Gereç ve Yöntem: Yaș ortalamaları 38,4 yıl olan 86 erkek ve 123 kadın olmak üzere 209 gönüllüde, sorgulama, nefelometrik yöntemle total IgE, fluoroimmünoassay yöntemi ile fadiotop ölçümleri ile beraber, apidae, vespidae ve polistes venomlarına karșı epidermal/intradermal test uygulayarak duyarlılașma oranlarını araștırdık.

Bulgular: Iki yüz dokuz olguda her üç venom türüne karșı duyarlılașma oranını \%21 bulduk. Venom duyarlılığı olan kișiler arasında birden çok venoma karșı duyarlı olanların oranı \%52,3 idi. Sorgulama sonucunda, arı sokması ile olușan reaksiyonların, \%80'inin normal reaksiyon, \%11'inin geniș lokal reaksiyon, \%9'unun sistemik reaksiyon olduğu bulundu. Geniș lokal reaksiyon tarif eden olguların $\% 23,5^{\prime}$ unda, sistemik reaksiyon tarif eden olguların $\% 21,5^{\prime}$ inde deri testi pozitif idi. Erkeklerle kadınlar arasında; stratifiye edilen yaș grupları arasında; total IgE pozitif ve negatif olanlar arasında; Phadiotop pozitifliği olanlar ve olmayanlar arasında; kırsal ve kentsel bölgede oturanlar arasında; arı sokma sayısı bakımından; son arı sokmasından itibaren geçen zaman açısından ve reaksiyon türleri bakımından duyarlılașma oranları arasında fark bulunmadı.

Sonuç: Mersin yöresinde arı venomlarına karșı duyarlılık oranının oldukça yüksek olduğu, ama duyarlılașma titrasyonunun düșük düzeyde olduğu; dolayısıyla arı venom alerjisinin önemli bir sağlık sorunu olabileceği görülmektedir. (Türkderm 2012; 46: 196-201) Anahtar Kelimeler: Alerji, atopi, hymenoptera venom duyarlılığı, deri testi

\section{Summary}

Background and Design: Allergic reactions to Hymenoptera venoms are significant health problems because of their serious outcomes. The aim of this study was to investigate the sensitization rates of Hymenoptera venoms (an indirect measure of Hymenoptera venom allergy) in Mersin region.

Materials and Methods: In this study, we investigated the sensitization rates among 209 volunteers ( 86 males, 123 females, mean age: 38.4 years) using questionnaires, total IgE determination with nephelometric method and phadiotop determinations with fluoroimmunoassay, epidermal/intradermal testing with Apidae, Vespidae and Polistes venom extracts.

Results: Sensitization rate to venoms of all three species were $21.0 \%$ among 209 subjects. Sensitization rate to more than one species simultaneously was $52.3 \%$ among Hymenoptera-sensitive subjects. With the aid of questionnaires we found that sting reactions were "normal reactions" in $80 \%$, "large local reactions" in $11.0 \%$ and "systemic reactions" in $9 \%$ of the subjects. The rate of positive skin tests was $23.5 \%$ among the subjects who described large local reactions and $21.5 \%$ among the subjects who described systemic reactions. There were no significant difference in the sensitization rates between males and females, in subjects stratified by age, subjects with elevated and normal total IgE values, subjects with positive and negative phadiotop determinations subjects living in urban and suburban areas and between subjects with respect to sting number or time elapsed since the last sting or the varieties of sting reactions.

Conclusion: Although low in titer, the sensitization rates to hymenoptera venoms were significantly high in Mersin region. Therefore, Hymenoptera venom allergy may contribute to health problems, significantly in this part of the country. (Turkderm 2012; 46: 196-201) Key Words: Allergy, atopy, Hymenoptera venom hypersensitivity, skin test 


\section{Giriş}

Hymenoptera grubuna ait böceklerin sokması sonucu meydana gelen alerjik yanıtlar, sivrisinek, atsineği, tahtakurusu gibi ısırma sonucu oluşan alerjik yanıtlara göre çok daha sık olarak meydana gelir. Hymenoptera sokmalarına bağlı oluşan akut alerjik reaksiyonlar sonucu, Avrupa ve Amerika'da her yıl yüzlerce kişi hayatını kaybetmektedir. Sokma sonucu ciddi sistemik reaksiyon oluşma olasılığı ise çok seyrektir. Alerjik reaksiyonların dışında toksik reaksiyonlar da meydana gelebilir ${ }^{1}$.

Hymenoptera grubu içinde en sık karşılaşılan böcek sokmaları, arılara bağlı olarak meydana gelenlerdir. Yedi buçuk milyon nüfuslu İsviçre'de 1961-2003 yılları arasında böcek sokmalarına -bunların çoğunluğunu arı sokmaları oluşturmaktadır- bağlı olarak meydana gelen 132 ölüm vakası bildirilmiştir ${ }^{1}$. Pek çok olgunun ise tanı konamama nedeni ile istatistiksel verilere giremediği kabul edilmektedir. Bu sebeple, nedeni belirlenemeyen ölümlerde arı veya ateş karıncası gibi böcek sokmalarının araştırılması önerilmektedir2.

Epidemiyolojik çalışmalarda, arı sokmalarında alerjik reaksiyon riski \%2,8-\%28,7 arasında değişmektedir3-5. On altı - 65 yaş grubunda yaşam boyu kümülatif arı sokma oranları \%61-95 arasındadır. Geniş lokal reaksiyonların oranı \%2,4 - \%26,4, sistemik reaksiyonların oranı \%0,37,5 olarak bildirilmiştir. Mortalite oranları ise yapılan çeşitli çalışmalara göre 0,03-0,48 /1000000 arasında değişmektedir6-8.

Arı venomları ile karşılaşma genellikle seyrek olarak meydana geldiği için ve zaman içinde amnestik yanıtlar da oluşabileceğinden, sensitizasyon (duyarlılık) ile ciddi alerjik yanıtlar arasında seyrek olarak ilişki bulunamamasına rağmen, duyarlılaşma, arı alerjisinin bir ölçüsü olarak alınabilir. Bu çalışmada, arı alerjisinin toplum sağlığı yönünden önemini göz önüne alarak, Mersin yöresinde, üç arı türüne karşı (apidae, vespidae, polistes) toplumda oluşan sensitizasyon oranlarını araştırmayı amaçladık.

\section{Gereç ve Yöntem}

iç Hastalıkları Polikliniklerine başvuran, herhangi bir hastalığı tespit edilmeyen, immün yetmezliği olmayan, immünosüpresif ilaç kullanmayan, kendisine arı testi yapılmasını kabul eden sağıklı gönülülerden oluşan 209 kişi çalışmaya dahil edildi. Çalışma için etik kurul izni alındı. Deri testini etkileyecek deri hastalığı olanlar ve dermografizmi olanlar çalışma dışında bırakıldı. Denekler son bir ay içinde antihistaminikler, antidepresif ilaçlar, kalsiyum antagonistleri ve ACE inhibitörleri gibi test sonucunu etkileyebilecek ilaçları alıp almadıkları konusunda sorgulandı ve uygun olmayan olgular çalışma kapsamı dışında bırakıldı. Her deneğe çalışma ve uygulanacak testler ile ilgili detaylı bilgi verilerek yazılı onay alındı. Test uygulamasından önce deneklerin demografik özellikleri, arı sokma sayısı, zamanı, sokan arının cinsini, meydana gelen reaksiyonun türünü araştırmak amacıyla sorgulama formları dolduruldu. Her denekten deri testi öncesinde total IgE ve fadiotop tayini için dört $\mathrm{ml}$ kan alınarak serumu ayrıldı ve bekletilmeden laboratuvara gönderildi.

Deri testleri için aköz immünoterapi ekstraktları kullanıldı (Stallergenes, Fransa). Apis mellifera için bu firmanın 63721 kod numaralı Alyostal venin, vespidae için 54210 kod numaralı, Polistes için 65833 kod numaralı alyostal ekstraktı kullanıldı. Lyofilize flakonlar 5,5 ml dilüent (kod no: 55601) ile "rekonstitue" edilerek stok solüsyonlar hazırlandı (100 $\mu \mathrm{g} / \mathrm{mL}$ ). Daha sonra her flakondan $0,5 \mathrm{~mL}$ çekilip 4,5 mL dilüentle karıştırılarak 1:10, 1:100, 1:1000, 1:10000 ve 1:100000'lik dilüsyonlar hazırlandı. Anafilaksi riskini azaltmak için teste 1:1000, 1:10000 dilüsyonlarda yapılan epikütan uygulama ile başlandı daha sonra intrakutan testlere geçildi. Yüksek konsantrasyonlarda lokal toksik yanıtların sık olarak meydana gelmesi nedeniyle de intrakütan testler için 1:100000, 1:10000, 1:1000 ve 1:100'lük konsantrasyonlar kullanıldı.

Deri testleri standart epidermal "puncture" ve intradermal test yöntemi kullanılarak yapıldı. "Puncture" test için Stallerpoint lanset (Stallergenes), intradermal testler için ise PPD veya insülin enjektörü kullanıldı. Epidermal test pozitif kontrolü olarak histamin kontrol (Stallergenes, kod: 30008796), epidermal ve intradermal testlerin negatif kontrolü olarak ekstraktların dilüe edildiği dilüent (kod no: 55601) kullanıldı. Testler her iki önkolun volar yüzü kullanılarak uygulandı ve 20 dakika sonra sonuçlar "wheal" reaksiyonunun ortogonal çaplarının toplamı üzerinden değerlendirildi. Negatif kontrol, 3 mm üzeri pozitif kabul edildi. "Flare" reaksiyonu "wheal" şartları gerçekleşiyorsa pozitiflik bulgusu olarak değerlendirildi. Teste sırasıyla 1:10000 ve 1:1000'lik epidermal testlerle başlanıp, intrakütan testlerin 1:100000, 1:10000, 1:1000, 1:100 konsantrasyonları ile devam edildi. Subkütan veya intrakütan testin pozitif olduğu aşamada test işlemi durduruldu ve daha yüksek konsantrasyonlara geçilmedi. Test sonuçları "wheal" in çevresi ince uçlu tükenmez kalemle çizilerek, ortogonal çapları milimetrik bölmeli cetvelle ölçülerek değerlendirildi. Testlerin uygulandığı noktaların birbirinden en az $4 \mathrm{~cm}$ uzak olmasına dikkat edildi.

Total IgE immünonefelometri yöntemle ölçüldü. Bu amaçla Dade Behring firmasının $\mathrm{N}$ latex IgE mono preparatı ve BN Prospere cihazı(USA) kullanıldı. Cut off değeri $\mathrm{lgE}>100 \mathrm{IU} / \mathrm{ml}$ olarak alındı. Fadiotop, fluoroenzimimmunassay yöntemi ile ölçüldü (ImmunoCAP Phadia İsveç). Sonuçlar 0- 6 arasında yedi sınıfta değerlendirildi. Klas 1'in üzeri yani 0,35 kU/l eşik değeri olarak alındı.

Veriler SPSS $(\mathrm{v} 16,0)$ istatistiksel programına kayıt edildi. Verilerin değerlendirilmesinde $2 \times 2$ düzende, çoklu gözlü düzenlerde, ki- kare testi kullanıldı.

\section{Bulgular}

Çalışmaya dahil edilen 209 olgunun 86'sı erkek (yaş ortalaması 37,67 SD: 15,32 yıl) 123'ü kadındı (yaş ortalaması 38,89 SD: 15,06 yıl). Kadınerkek sayısı ve yaş ortalamaları arasında önemli fark bulunmadı ( $p>0,005)$. Toplam 209 olgunun yaş ortalaması 38,4 SD: 15,1 yıl olup yaş sınırı 17-78 yaşlar arasında değişiyordu.

Çalışmaya katılan 209 olgunun epidermal ve intradermal test sonuçları ile cinsiyet, yaş, total IgE, faditop, yerleşim bölgesi, arı sokma sayısı, arı sokma zamanı ve reaksiyon türlerine ait frekans değerleri Tablo 1 ve Grafik 1'de verilmiştir. Yaş grupları arasında test pozitifliği açısından

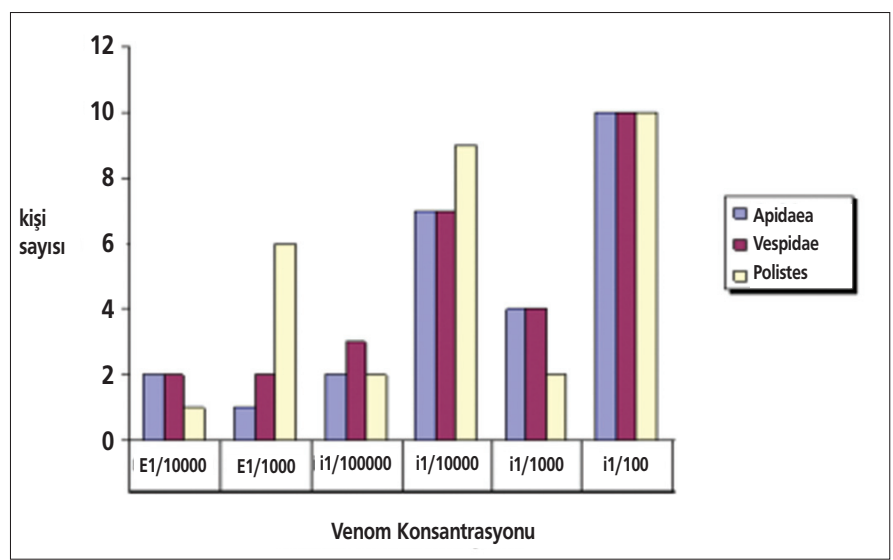

Grafik 1. Epidermal ve intradermal test sonuçlarına göre hastalarda Apidae, Vespidae ve Polistes duyarlılaşması görülme sıklığının grafiği 
önemli bir fark bulunmadı (Tablo 1). Total IgE değerleri pozitif bulunan hastalardaki sensitizasyon oranları ile negatif olanlar arasındaki sensitizasyon oranları birbirine benzerdi. Fadiotop pozitifliği olan olgulardaki sensitizasyon oranları fadiotopu negatif bulunan olgulardaki sensitizasyon oranlarından farklı değildi. Yerleşim bölgeleri göz önüne alındığında kırsal bölgelerde sensitizasyon oranı kentte yaşayanlar göre daha yüksek olmakla birlikte $p$ değeri marjinal kaldı ve bu istatistiksel bir öneme sahip değildi. Arı sokma sayısı bakımından da duyarlı olan olgularla olmayanlar arasında önemli bir fark bulunmadı. Son arı sokma zamanları göz önüne alındığında duyarlı olan olgularla olmayanlar arasında yine fark bulunamadı. Toplam 209 olgudan 155'inde arı sokması hikayesi var olup, 32 tanesinde deri testi pozitif, 123 tanesinde de negatif bulundu. Deri testi pozitif olan 32 olgunun \%78 normal reaksiyon, \%12,5 geniş lokal reaksiyon ve \%9,3 sistemik reaksiyon hikayesi mevcuttu (Tablo 1). Reaksiyon türleri arasında deri testi pozitif ve negatif bulunan olgular arasında önemli fark bulunmadı.

Kırk dört olguda tespit edilen 84 pozitifliğin 26 tanesi (\%31) apidae venomlarına, 28 tanesi (\%33) vespidae venomlarına 30 taneside (\%36) polistes venomlarına karşı oluştu (Tablo 2). Konsantrasyonlar ile test pozitifliği arasında önemli bir fark yoktu ( $p>0,005)$.

Birden fazla venoma duyarlı olan olguların dağılımı Tablo 3A, 3B ve 3C'de gösterilmiştir. Deri testi pozitif bulunan 44 hastadan $15^{\prime}$ inde her üç

Tablo 1. Arı testleri pozitif ve negatif bulunan kişilerde cinsiyet, yaş, total IgE, fadiotop, yerleşim yeri, arı sokma sayısı, zamanı ve reaksiyon türü değişkenlerinin birleştirilmiş frekans tablosu

\begin{tabular}{|c|c|c|c|c|c|}
\hline \multicolumn{2}{|l|}{ Değişkenler } & Test $(+)$ & Test (-) & Toplam & $\mathbf{P}$ \\
\hline \multirow[t]{3}{*}{ Cinsiyet } & Erkek & $15(\% 34)$ & $71(\% 43)$ & $86(\% 41)$ & \multirow{3}{*}{0,3690} \\
\hline & Kadın & $29(\% 66)$ & $94(\% 57)$ & $123(\% 59)$ & \\
\hline & Toplam & $44(\% 100)$ & $165(\% 100)$ & $209(\% 100)$ & \\
\hline \multirow[t]{7}{*}{ Yaş } & $10-19$ & $4(\% 10)$ & $9(\% 5)$ & $13(\% 6)$ & \multirow{7}{*}{0,8377} \\
\hline & $20-29$ & $16(\% 36)$ & $51(\% 31)$ & $67(\% 32)$ & \\
\hline & $30-39$ & $7(\% 16)$ & $27(\% 16)$ & $34(\% 16)$ & \\
\hline & $40-49$ & $7(\% 16)$ & $36(\% 22)$ & $43(\% 21)$ & \\
\hline & $50-59$ & $5(\% 11)$ & $25(\% 16)$ & $30(\% 14)$ & \\
\hline & $60<$ & $5(\% 11)$ & $17(\% 10)$ & $22(\% 11)$ & \\
\hline & Toplam & $44(\% 100)$ & $165(\% 100)$ & $209(\% 100)$ & \\
\hline \multirow[t]{3}{*}{ Total lgE } & $(+)$ & $4(\% 12)$ & $30(\% 28)$ & $34(\% 24)$ & \multirow{3}{*}{0,0976} \\
\hline & $(-)$ & $29(\% 88)$ & $76(\% 72)$ & $105(\% 76)$ & \\
\hline & Toplam & $33(\% 100)$ & $106(\% 100)$ & $139(\% 100)$ & \\
\hline \multirow[t]{3}{*}{ Phadiotop } & $(+)$ & $6(\% 18)$ & $13(\% 12)$ & $19(\% 14)$ & \multirow{3}{*}{0,5659} \\
\hline & $(-)$ & $27(\% 82)$ & $93(\% 88)$ & $120(\% 86)$ & \\
\hline & Toplam & $33(\% 100)$ & $106(\% 100)$ & $139(\% 100)$ & \\
\hline \multirow[t]{3}{*}{ Yerleşim Yeri } & Kırsal Bölge & $13(\% 30)$ & $37(\% 22)$ & $50(\% 24)$ & \multirow{3}{*}{0,0857} \\
\hline & Kentsel Bölge & $31(\% 70)$ & $128(\% 78)$ & $159(\% 76)$ & \\
\hline & Toplam & $44(\% 100)$ & $165(\% 100)$ & $209(\% 100)$ & \\
\hline \multirow[t]{7}{*}{ Arı Sokma Sayısı (Adet) } & 0 & $13(\% 30)$ & $41(\% 25)$ & $54(\% 26)$ & \multirow{7}{*}{0,5064} \\
\hline & 1 & $14(\% 32)$ & $44(\% 27)$ & $58(\% 28)$ & \\
\hline & 2 & $10(\% 23)$ & $40(\% 24)$ & $50(\% 24)$ & \\
\hline & 3 & $5(\% 11)$ & $17(\% 10)$ & $22(\% 11)$ & \\
\hline & 4 & 0 & $13(\% 8)$ & $13(\% 6)$ & \\
\hline & 5 & $2(\% 4)$ & $10(\% 6)$ & $12(\% 5)$ & \\
\hline & Toplam & $44(\% 100)$ & $165(\% 100)$ & $209(\% 100)$ & \\
\hline \multirow[t]{5}{*}{ Son Arı Sokma Zamanı (Yıl) } & $0-3$ & $5(\% 16)$ & $15(\% 12)$ & $20(\% 13)$ & \multirow{5}{*}{0,4436} \\
\hline & $4-8$ & $10(\% 31)$ & $36(\% 30)$ & $46(\% 30)$ & \\
\hline & $9-15$ & $12(\% 37)$ & $35(\% 28)$ & $47(\% 30)$ & \\
\hline & $15<$ & $5(\% 16)$ & $37(\% 30)$ & $42(\% 27)$ & \\
\hline & Toplam & $32(\% 100)$ & $123(\% 100)$ & $155(\% 100)$ & \\
\hline \multirow[t]{4}{*}{ Reaksiyon Türü } & Normal & $25(\% 78)$ & $99(\% 80)$ & $124(\% 80)$ & \multirow{4}{*}{0,9481} \\
\hline & Geniş Lokal Reaksiyon & $4(\% 13)$ & $13(\% 11)$ & $17(\% 11)$ & \\
\hline & Sistemik Reaksiyon & $3(\% 9)$ & $11(\% 9)$ & $14(\% 9)$ & \\
\hline & Toplam & $32(\% 100)$ & $123(\% 100)$ & $155(\% 100)$ & \\
\hline
\end{tabular}




\section{Tablo 2. 44 olguda tespit edilen 84 test pozitifliğinin venom türlerine göre dağılım tablosu}

\begin{tabular}{|c|c|c|c|c|c|}
\hline Konsantrasyon & Apidae & Vespidae & Polistes & Toplam & $\mathbf{P}$ \\
\hline Epidermal $1: 10000$ & $2(\% 8)$ & $2(\% 7)$ & $6(\% 20)$ & $10(\% 12)$ & 0,2019 \\
\hline Epidermal 1:1000 & $1(\% 4)$ & $2(\% 7)$ & $1(\% 3)$ & $4(\% 5)$ & 0,7788 \\
\hline Intradermal $1: 100000$ & $2(\% 8)$ & $3(\% 11)$ & $2(\% 7)$ & $7(\% 8)$ & 0,8669 \\
\hline Intradermal 1:10000 & $7(\% 27)$ & $7(\% 25)$ & $9(\% 30)$ & $23(\% 27)$ & 0,8404 \\
\hline İntradermal $1: 1000$ & $4(\% 15)$ & $4(\% 14)$ & $2(\% 7)$ & $10(\% 12)$ & 0,7165 \\
\hline Intradermal $1: 100$ & $10(\% 38)$ & $10(\% 36)$ & $10(\% 33)$ & $30(\% 36)$ & 1,000 \\
\hline Toplam & $26(\% 100)$ & $28(\% 100)$ & $30(\% 100)$ & $84(\% 100)$ & \\
\hline
\end{tabular}

\section{Tablo 3. Birden fazla venoma duyarlı olan olguların dağılımı}

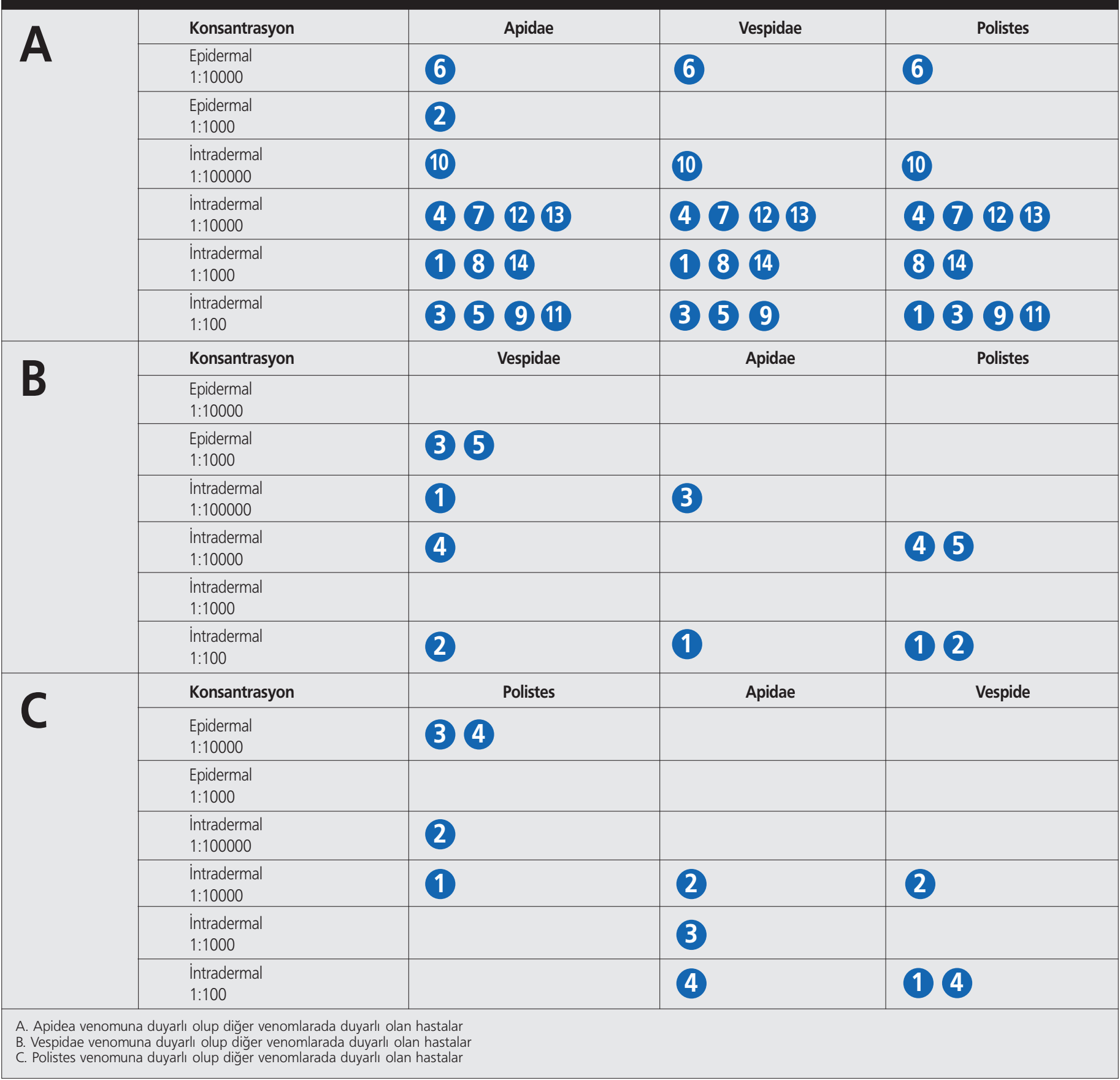


venom türüne karşı, apidea ve polistes için 4'ünde, apidae ve vespidae için 2'sinde, polistes ve vespidae için 2'sinde duyarlılaşma olduğu saptandı. Deri testi pozitif bulunan olgular arasında aynı test konsantrasyonun da her üç antijene karşı duyarlı bulunan kişilerin oranı 15/44 (\%34)'tü. Yine aynı test konsantrasyonunda apidae ve vespidae karşı 2/44 $(\% 4,5)$; apidae ve polistese karşı 2/44 $(\% 4,5)$; vespidae ve polistese karşı test pozitifliği oranı 3/44 $(\% 6,8)$ bulundu. Daha düşük konsantrasyonda pozitif bulunan testler esas antijen ("Cognate antijen") daha yüksek konsantrasyonda bulunanlar ise çapraz reaktif olarak ele alındığında apidea ve polistes'e karşı duyarlaşma oranı \%9 (4/44) apidae ve vespidaeye karşı \%4,5 (2/44), polistes ve vespidae için \%4,5 (2/44) olarak saptandı. Birden çok venom ile duyarlı cilt testi pozitif olanlar olguların oranı \%52,3 olarak bulundu.

\section{Tartışma}

Türkiye'nin güney bölgesinde yaşayan kişiler arasında, apidae, polistes ve vespidae venomlarına karşı toplumda önemli düzeyde duyarlılaşma vardır. İki yüz dokuz kişi üzerinde yaptığımız çalışmamızda Mersin yöresinde en az bir venoma karşı duyarlılı̆̆ı \%21 olarak saptadık. Bu oran kırsal bölgede yaşayan kişiler arasında \%26, kentsel bölgede yaşayanlar arasında \%14 idi. Fakat aradaki fark istatistiksel öneme sahip değildi.

Bizim çalışmamızda sorgulama kağıtlarından elde ettiğimiz sonuçlara göre 17-74 yaş sınırı içindeki iki yüz dokuz olguda arı sokmasına maruz kalma oranı \%74 olduğu görülmektedir. Antonicelli ve arkadaşlarının yaptığı litaratür taramasına bağı araştırmada hayatının belli bir döneminde hymoneptera sokmalarına maruz kalan kişilerin oranı \%56,694,5 arasında olduğunu bulunmuştur ${ }^{9}$. Incorvaia ve arkadaşlarının İtalya'da Piacenza askeri hastanesinde askere alınan 20 yaşlarındaki 701 olguda 1994 yılında yaptıkları araştırmada arı sokmasına maruz kalanların oranı \%56,6 olarak saptanmıştır10. Yine Charpin ve arkadaşlarının Fransa' da 1984-1988 yılları arasında 18-65 yaş grubundaki 8271 olguda arı tarafından sokulma oranını \%65 bulmuşlardır11. İsrail'de Graif ve arkadaşlarının 13-14 yaş grubundaki olgular arasında yaptığı çalışmada 10021 öğrencide yaşamları süresince en az bir defa arı sokması görülme sıklığını \%56,3 (5644 olgu) bulmuşlardır12. Navarro ve arkadaşlarının İspanya'da yaptığı araştırmada bir otomobil fabrikasında çalışan 21-67 yaşları arasında 1015 erkek ve 49 kadın arasında araştırmada arı sokma maruziyeti \%84,1 olarak saptanmışı ı ${ }^{3}$. Orhan ve arkadaşlarının 137 Türk çocuğunda retrospektif anafilaksi araştırmasında Hymenoptera venomu \%37,5 oranında neden olarak kaydedilmiştir ${ }^{13}$. Türkiye'de Kalyoncu ve arkadaşları tarafından Afyon'un Çay ilçesinde kağıt fabrikasında çalışan iş̧̧iler ve ailelerinden oluşan 786 kişilik grupta yapılan araştırmada kümülatif arı sokmasına maruz kalma oranını \%94,5 bulmuşlardır ${ }^{14}$. Görüldüğü gibi arı sokmasına maruz kalma oranları ılıman iklim bölgesinde bulunan yerleşim alanlarında oldukça yüksek oranlarda bulunmaktadır. Soğuk iklim kuşağında bulunan bölgelerde yapıımış çalışmalara ait yeterli veri bulunmamakla birlikte, bu bölgelerde arı venomu ile duyarlı olan insanların oranının oldukça düşük bulunuyor olması maruziyet oranının da bu bölgelerde düşük olabileceğini düşündürmektedir. Arıların aktif olarak hareket edebilmesi için sıcaklığın $10-30{ }^{\circ} \mathrm{C}$ derece olması gereklidir. Her ne kadar kümülatif maruziyet oranı oldukça yüksek bulunsa bile arı venomu ile karşılaşma sıklığı oldukça düşüktür. Bizim araştırmamızda bir kez arı sokmasına maruz kalanların oranı \%28, iki kez maruz kalanların oranı \%24, üç kez maruz kalanların oranı \%11, dört kez maruz kalanların oranı \%6, beş ve beşten fazla maruz kalanların oranı \%5 olarak bulunmuştur. Bu oranlardan kolayca görüleceği gibi tekrarlayan antijenik uyarı oranı çok düşüktür. Dolayısıyla amnestik yanıtların oluşması veya çok düşük antikor titresi nedeni ile deri testlerinde saptanan duyarlılaşma oranlarının olması gerekenden daha düşük oranda bulunacağını söyleyebiliriz.

Çalışmamızda 209 kişinin \%21'nde üç arı venomuna karşı deri testi pozitifliği bulduk. Yunanistan'da 1991-1992 yılları arasında Grigoreas ve arkadaşları tarafından yapılan bir araştırmada 20-60 yaş grubundaki 480 erişkinde duyarlılaşma oranı deri testi ile \%34,2 olarak saptanmıştır15. Golden ve arkadaşları, Baltimor (ABD) bölgesinde 269 fabrika çalışanı üzerinde apidae ve vespidae venomu kullanılarak yaptıkları araştırmada sensitizasyon oranını \%17 bulmuşlardır8.

Sayıları nispeten sınırlı olan, buraya kadar değindiğimiz in vivo testlerin yanında literatürde in vitro testleri kullanarak arı venom duyarlılaşmasını araştıran başka çalışmalar da vardır. Bazı araştırmacılar ise duyarııığı ve özgüllüğü deri testinden düşük olan in vitro testleri kullanarak arı venom alerji prevalansını araştırmışlardır. Stuckey ve arkadaşlarının Avustralya'da genel popülasyonda yaptığı araştırmada, 3439 kişide \%16 oranında arı venomlarına karşı RAST yöntemi ile duyarlılaşma olduğunu bulmuşlardır16. Herbert ve Salkie'nin Kanada'da 86 ofis çalışanında, yine RAST testi kullanarak yaptıkları araştırmalarında apidae ve vespidae türlerine karşı \%12 oranında duyarlaşma olduğu belirtilmiştir ${ }^{17}$. Bunlara karşılık soğuk iklim kuşağında bulunan İsveç'te Björnsson ve arkadaşları, 20-44 yaşlar arasındaki 1399 olguda apidae ve vespidae venomlarına karşı duyarlılaşma oranını RAST yöntemi ile \%9,3 bulmuşlardır ${ }^{18}$. Bizım çalışmamızda ise 20-40 yaş grubunda deri testi ile bulunan pozitiflik oranı \%22,8'dir. Her ne kadar, in vivo ve in vitro testler arasında duyarlıık ve özgüllük değerleri farkılık gösteriyorsa da iklim koşulları ile maruziyet ve duyarlılaşma arasında bir ilişki bulunabileceği anlaşılmaktadır. Erdman ve arkadaşlarının 2004 yılında Almanya'da vespidae venomu kullanarak sistemik reaksiyon veren 50 olgu ve 20 kişilik kontrol grubu üzerinde yaptıkları araştırmada RAST testinin duyarlılığının in vivo testlere göre \%76 oranında pozitif bulunduğunu; yine in vivo testlerle karşılaştırıldığında bazofil aktivasyon testinin \%92 oranında pozitif bulunduğunu bildirmişlerdir ${ }^{19}$. Deri testinin duyarlılığı in vitro testlerden yüksektir?

Grigoreas ve arkadaşlarının yaptığı çalışmada, arı alerjisi anamnezi vermeyen kişiler arasında cilt testi ile \%28,7 oranında sensitizasyon saptanmıştır15. Golden ve arkadaşlarının yaptığı çalışmada ise bu oran $\% 15^{\prime}$ tir8. Marszalska ve arkadaşlarının Polonya'nın Wroclaw şehrinde yaptığı çalışmada 20-44 yaşları arasında 169 olgu üzerinde yaptığı araştırmada 146'sına deri testi, 132'sine RAST yöntemi ile spesifik IgE bakılmış, serum IgE ve/veya deri testi ile arı allerjisi anemnezi vermeyenlerin \%17,1'inde sensitizasyon saptanmıştır ${ }^{4}$. Bizim çalışmamızda ise bu oranı \%20 (25/124) olarak bulduk. Yine çalışmamızda hiç arı sokmasına maruz kalmadığını belirten 54 olgunun \%24'ünde deri testi pozitifliği bulduk. Tabii ki burada deneklerin sorgulama sırasında çok önceden olan hatırlayamamış olmalarının rolü bulunabilir. Ama bu durumu esas açıklayacak konu çapraz duyarlama olayıdır. Bilindiği gibi arı venomları içindeki antijenik yapılar diğer böceklerin venomları ve vücut salgıları içinde de bulunabilmektedir. Bunun en güzel örneği vespid venomunda bulunan fosfolipaz A1'in aynı zamanda Solenopsis invicta venomunda da bulunuyor olmasıdır. Türkiye'de Çukurova bölgesinde Solenopsis invicta kolonileri mevcuttur fakat bunun epidemiyolojik önemi henüz araştırılmamıştır. Aynı şekilde Selonopsis invita venomunda bulunan fosfolipaz A1'in filojenetik benzerlik nedeniyle bu bölgede yaşayan diğer karınca türlerindede bulunması muhtemeldir. Keza vespid venomunda bulunan Antijen 5 ile Selonopsis invicta venomunda bulunan Sol i3 antijenleri arasında \%50 oranında benzerlik vardır20. Bu şekilde karınca belki başka böcek türlerine ait çapraz duyarlılaşmasının hiç arı sokmasına maruz kalmayan kişilerdeki 
deri testi pozitifliğini açıklaması mümkün olabilir. Diğer taraftan şifalı olduğu gerekçesiyle tüketilen arı sütü gibi arı vücut ekstraklarının alınmasıyla da çapraz duyarlılaşma meydana geliyor olabilir.

Çalışmamızda kırsal bölgede yaşayan kişilerde deri testi pozitifliğini \%26 oranında pozitif bulduk; kentsel bölgede yaşayan kişilerde deri testi pozitifliğini \%14 oranında deri testi pozitifliği bulduk. Grigoreas ve arkadaşlarının Yunanistan'da yaptığı araştırmada bu oranları yine aynı sırayla \%35,8 ve \%17,8 bulmuşlardır15. Kırsal ve kentsel bölgelerde bulunan yerleşim arasındaki bu fark; kırsal ve kentsel arı popülasyonlarının sayısı arasındaki ve kırsal ve kentsel bölgelerdeki yaşam farklılıklarından kaynaklanıyor olabilir. Kırsal alanlarda arı sayısının kentlerden daha fazla olması, bağ bahçe işleriyle daha fazla uğraşıııor olması, evin dışında geçirilen zamanın kentlerdekine göre daha fazla olması, ağaçların ve tek katlı, çatıları yuva kurmaya elverişli evlerin bulunması, arıcılıkta daha çok kırsal alanda yapılıyor olması nedeniyle arılarla temas daha fazla olmaktadır.

Çalışmamızda erkek popülasyonda sensitizasyon oranını \%17,4, kadın popülasyonda ise \%23,5 olarak bulduk. Bu oranlar diğer çalışmalarda yapılan çalışmalardan oldukça farkıdır. Grigoreas ve arkadaşlarının Yunanistan'da yaptığı çalışmada erkeklerde oran \%34,2, kadınlarda ise \%25 olarak saptanmıştır ${ }^{15}$. Literatürde erkeklerde duyarılışma oranının kadınlardan yüksek oranda olduğunu bildiren çalışmalar da vardır. Bizim çalışmamızda bulduğumuz bu oranlardaki farklııı̆ın çalışmanın yapıldığı bölgedeki kültürel faktörlerle ilişkili olduğunu düşünüyoruz. Bu bölgede tarla, bağ ve bahçe işleri çoğunlukla kadınlar tarafından yapılmaktadır. Çalışmamızda deri testi pozitif bulunan olgular arasında aynı test konsantrasyonun da her üç antijene karşı duyarlı bulunan kişilerin oranı \%34 dür. Yine aynı test konsantrasyonun da apidae ve vespidae karşı $\% 4,5$; apidae ve polistese karşı \%4,5; vespidae ve polistese karşı test pozitifliği oranı $\% 6,8$ olarak bulundu. Birden çok venoma karşı deri testi pozitif olan olguların oranı \%52,3 olarak saptadık. Çalışma grubunda, apidae venomuna karşı deri testi pozitifliği oranı \%2, vespidae venomuna karşı deri testi pozitifliği oranı \%4, polistes venomuna karşı deri testi pozitifliği oranı \%5 olarak bulduk. Grigoreas ve arkadaşlarının Yunanistan'da yaptığı çalışmada deri testi pozitifliği olan vakalarda çoklu duyarlanma oranı \%38,9 olarak bulunmuştur. Deri testi pozitif olan olgularda apidae için $\% 15,9$, polistes için $\% 9,5$, vespidae için \%35,7 duyarlanma, apidae ve polistes beraber duyarlanma \%1,3, apidae ve vespidae için $\% 10,2$, polistes ve vespidae için $\% 17,2$, her üç venomla sensitize olanların oranı \%10,2 olarak saptanmıştı115. Golden ve arkadaşlarının Amerika Birleşik Devletleri'nde yaptığı çalışmada 269 kişiden 47 (\%17)'sinde apidae ve vaspidae venomlarına karşı, apidae venomuna karşı $\% 5$, vespidae venomuna karşı $\% 14$ deri testi pozitifliği saptanmıştır8. Kalyoncu ve arkadaşlarının Türkiye'de yaptığı çalışmada öyküsünde alerjik reaksiyon tanımlayan 212 olguda yapılan RAST testinde apidaeler için spesifik IgE oranını \%16,5, vespidaeler için spesifik IgE oranını \%20,2 olarak bulmuştur ${ }^{14}$. Vespidae venomuna karşı duyarlanmanın apidae venomundan daha sık olduğu görülmektedir. Bunun nedeni vespidlerin apidlere göre daha saldırgan tavırlı olmaları ve bu nedenle sokma intimalinin yüksek olmasından kaynaklanıyor olabilir. Çalışmamızda bulduğumuz arı sokmasına bağlı reaksiyonların oranları (normal reaksiyon oranı \%80,1, geniş lokal reaksiyon 10,9, sistemik reaksiyon oranı \%9) literatürde bulunan oranlara benzerdir.

Araştırmamızda hymenoptera sokması sonucunda olguların \%11'inde geniş lokal reaksiyon, \%9'unda sistemik reaksiyon geliştiği saptanmıştır. Bu bulgular literatürdeki diğer araştırmaların bulguları ile uyumludur. Birden fazla arı venomu ile duyarlanma oranı \%11 olarak bulundu. Arı sokmasına bağlı olarak geniş lokal reaksiyon tarif eden olguların \%23,5' inde, sistemik reaksiyon tarif eden olguların \%21,5'inde bu venomlara karşı yapılan deri testi pozitif bulunmuştur. Sistemik reaksiyon tarif eden olgularımızdaki deri testi oranının literatürler de bildirilen oranlardan daha düşük olması çalışmamıza dahil edilen denekler arasında arı sokma sayısının az olması, son arı sokma zamanı ile araştırmamızın yapıldığı zaman arasındaki sürenin fazla olması ile açıklanabilir.

Deri testi pozitifliği ile, cinsiyet, yaş, arı sokma sayısı ve son arı sokma zamanı arasında bir korelasyon bulunmamıştır. İstatistiksel olarak sınırda kalmasına rağmen kadınlar arasında sensitizasyon oranının erkeklerden daha yüksek olması çalışmanın yapıldığı bölgedeki kültürel özelliklere bağıı olabilir (Kadınların erkeklere göre bağ ve bahçe işlerinde daha çok çalışıyor olması).

Çalışmamızda total lgE ve fadiotop pozitifliği gibi atopi ile ilişkili olan faktörler ile venom duyarlılaşması arasında bir ilişki bulunmamıştır. Sonuç olarak Mersin yöresinde arı venomlarına karşı duyarlılık oranının oldukça yüksek olduğu, ama duyarlılaşma titrasyonunun düşük düzeyde olduğu; dolayısıyla arı venom alerjisinin önemli bir sağlık sorunu olabileceği görülmektedir.

\section{Kaynaklar}

1. Muller UR: Hymenoptera venom hypersensitivity: an update. Clin Exp Allergy 1998;28:4-6.

2. Schwartz MW, Pool WR, Bieber AL: Mojave rattlesnake (Crotalus scutulatus scutulatus) venom: enzyme activities and purification of arginine ester hydrolases. Toxicon 1984;22:327-38.

3. Navarro LA, Pelaez A, de la Torre F, et al: Epidemiological factors on hymenoptera venom allergy in a Spanish adult population. J Investig Allergol Clin Immunol 2004;14:134-41.

4. Nittner-Marszalska M, Liebhart J, Liebhart E, et al: Prevalence of Hymenoptera venom allergy and its immunological markers current in adults in Poland. Med Sci Monit 2004;10:CR324-9.

5. Fernandez J, Blanca M, Soriano V, Sanchez J, Juarez C: Epidemiological study of the prevalence of allergic reactions to Hymenoptera in a rural population in the Mediterranean area. Clin Exp Allergy 1999;29:1069-74.

6. Golden DB: Insect sting anaphylaxis. Immunol Allergy Clin North Am 2007;27:261-72, vii.

7. Ebo DG, Hagendorens MM, Stevens WJ: Hymenoptera venom allergy. Expert Rev Clin Immunol 2005;1:169-75.

8. Golden DB, Marsh DG, Kagey-Sobotka A, et al: Epidemiology of insect venom sensitivity. JAMA 1989;262:240-4.

9. Antonicelli L, Bilo MB , Bonifazi F: Epidemiology of Hymenoptera allergy. Curr Opin Allergy Clin Immunol 2002;2:341-6.

10. Incorvaia C, Mauro M, Pastorello EA: Hymenoptera stings in conscripts. Allergy 1997;52:680-1.

11. Charpin D, Birnbaum J, Lanteaume A, Vervloet D: Prevalence of allergy to hymenoptera stings in different samples of the general population. J Allergy Clin Immunol 1992;90:331-4.

12. Graif $\mathrm{Y}$, Romano-Zelekha $\mathrm{O}$, Livne I, Green MS, Shohat T: Allergic reactions to insect stings: results from a national survey of 10,000 junior high school children in Israel. J Allergy Clin Immunol 2006;117:1435-9.

13. Orhan F, Canitez Y, Bakirtas A, et al: Anaphylaxis in Turkish children: a multicentre, retrospective, case study. Clin Exp Allergy 2011;41:1767-76.

14. Kalyoncu AF, Demir AU, Ozcan $U$, et al: Bee and wasp venom allergy in Turkey. Ann Allergy Asthma Immunol 1997;78:408-12.

15. Grigoreas C, Galatas ID, Kiamouris C , Papaioannou D: Insect-venom allergy in Greek adults. Allergy 1997;52:51-7.

16. Stuckey M, Cobain T, Sears M, Cheney J, Dawkins RL: Bee venom hypersensitivity in Busselton. Lancet 1982;2:41.

17. Herbert FA, Salkie ML: Sensitivity to hymenoptera in adult males. Ann Allergy 1982;48:12-3.

18. Bjornsson E, Janson C, Plaschke P, Norrman E, Sjoberg O: Venom allergy in adult Swedes: a population study. Allergy 1995;50:800-5.

19. Erdmann SM, Sachs B, Kwiecien R, et al: The basophil activation test in wasp venom allergy: sensitivity, specificity and monitoring specific immunotherapy. Allergy 2004;59:1102-9.

20. Hoffman DR: Allergens in Hymenoptera venom XXIV: the amino acid sequences of imported fire ant venom allergens Sol i II, Sol i III, and Sol i IV. J Allergy Clin Immunol 1993;91:71-8. 